\title{
EFFECT OF COCO PEAT PARTICLE SIZE FOR THE OPTIMUM GROWTH OF NURSERY PLANT OF GREENHOUSE VEGETABLES
}

\author{
HKMS Kumarasinghe ${ }^{1 *}$, S Subasinghe ${ }^{1}$ and D Ransimala ${ }^{2}$ \\ ${ }^{1}$ Department of Crop Science, Faculty of Agriculture, University of Ruhuna, Sri Lanka \\ ${ }^{2}$ Coco Pel Lanka (Pvt) Kuttigala, Embilipitiya, Sri Lanka
}

Accepted: $24^{\text {th }}$ June 2015

\begin{abstract}
Coconut coir peat (CP) is an organic renewable source which is an environmentally sound substitute for peat as a soilless growing media for containerized nurseries in the world. Coco peat consists of short fiber $(<2 \mathrm{~cm})$ around 2 $-13 \%$ of the total and contains cork like particles ranging in sizes from granules $(4-5 \mathrm{~mm})$ to fine dust $(0.1 \mathrm{~mm})$. This huge range of particle size makes big variation on physical, chemical and biological properties of coco peat. When coco peat is used as a substrate for raising seedlings in soilless cultivation systems, optimizing of physical, chemical and biological properties are essential to produce vigorous healthy seedlings. Therefore, the aim of this study was to select the most suitable particle size range for coco peat to be used as a nursery substrate to produce greenhouse tomato, bell pepper, cucumber and cabbage seedlings. Six to nine months old coconut coir pith was used and the buffering was done using calcium nitrate $\left(4 \mathrm{~kg} / \mathrm{m}^{3}\right.$ of water). Fine $(\leq 0.5 \mathrm{~mm})$, medium $(3 \mathrm{~mm}-0.5$ $\mathrm{mm})$ and coarse $(4 \mathrm{~mm}<)$ particle ranges were separated using set of sieves. Completely randomized design with five replicates was used. Four separate experiments were conducted for tomato, bell pepper, cucumber and cabbage. Germination percentage, no. of leaves per seedling and seedling height were recorded as growth parameters during the nursery period. Highest germination percentage of tomato $(95 \%)$, bell pepper $(88 \%)$ and cucumber $(84 \%)$ were observed in medium size particle range and the fine particle range resulted the highest germination value in cabbage (94\%). The highest no. of leaves per seedling of tomato (7.2) and bell pepper (6.1) were recorded in medium size particle range and in cucumber (4.8) and cabbage (6.5) the fine particle range gave the highest value. The highest maximum seedling heights of tomato $(17.2 \mathrm{~cm})$, bell pepper $(20.3 \mathrm{~cm})$, cucumber $(14.3 \mathrm{~cm})$ and cabbage $(8.0 \mathrm{~cm})$ were observed in medium size particle range media. Overall results revealed that, medium size $(3 \mathrm{~mm}-0.5 \mathrm{~mm})$ particle range of coco peat is the best for practicing nurseries of tomato, bell pepper, cucumber and cabbage in greenhouse cultivations.
\end{abstract}

Key words: bell pepper, cabbage, coco peat, cucumber, particle size, tomato

\section{INTRODUCTION}

Coconut (Cocos nucifera L), is being largely exploited for its kernel which is the raw material for coconut oil. During the exploitation, the spongy pericarp (husk) is left as a byproduct which often serves as a raw material for coir fiber. The elastic cellular cork like pithy material forming the non-fibrous tissue of the husk is generally referred to as the coir pith, which accounts for $50-60 \%$ of the total weight of the husk. Nagarajan et al. (1985) mentioned that in the coir industry, every 10,000 husks generate approximately one ton of coir pith. In recent years, there has been a dramatic increase in the use of coconut coir peat as an environmentally sound peat substi-

*Corresponding author:sarathkumarasinghe@yahoo.com tute in soilless growing media for containerized nursery and crop production (Evans and Stamps, 1996; Handreck, 1992, 1993; Mak and Yeh, 2001; Meerow, 1994, 1995; Noguera et al., 1997, 2000; Offord et al., 1998; Stamps and Evans, 1997, 1999). Waste-grade coir may be finally sieved to remove fiber parts and the remaining product is used as the coir peat. Then bricks or bails are prepared after drying and compressing this coco peat (Evans and Stamps, 1996; Evans et al., 1996; Konduru et al., 1999). Although Sri Lanka is a leading manufacturer and an exporter of plant growing substrates derived from coco peat, their availability for local horticultural industries is very limited. A good plant growing substrate must be able to provide water, nutrients and oxygen for the plants as well as a 
good physical support. Therefore, the physical and chemical analyses of these substrates have been a matter of concern throughout the world over the last decade (Kang et al., 2004). Miller and Jones, (1995) stated that, the purpose of a potting media is to satisfy the needs for good seedling growth within the limited space of a container and to prepare it for successful transplanting into the field. In order to allow a rapid growth of seedlings, a healthy, fibrous root system is necessary and the growing media is the foremost factor determining it. The particle size of the materials utilized in growing media should be within an appropriate range to provide all suitable conditions to seedlings as small volumes of substrate per plant is used. The growing media should have various favourable characters such as light-weight. good porosity, well-drained but with optimum water holding capacity, slightly acidic with optimum cation-exchange-capacity, constant volume when wet or dry, lack of insects, diseases and weed seeds, low content of silt, clay and ash, easy storage for long periods of time without changes in physical and chemical properties and easy handling and blending (Miller and Jones, 1995). When raising seedlings in soilless cultivation systems, consistency of physical, chemical and biological properties are essential to produce vigorous healthy seedlings. Therefore, the aim of this study was to select the most suitable particle size range of coco peat as a nursery substrate to produce greenhouse tomato, bell pepper, cucumber and cabbage seedlings.

\section{MATERIALS AND METHOD}

A series of experiments were carried out at the site of Cocopel Lanka (Pvt) Ltd at Kuttigala, Embilipitiya from November 2009 to December 2012. Some chemical and physical properties of coco peat were analyzed at the substation of soil and plant nutrition division of TRI (Tea Research Institute) at Walahanduwa, Galle Sri Lanka.

Six to nine months old coco pith was used. Coco pith was first sieved by a rotary sieve $(8$ $\mathrm{x} 8 \mathrm{~mm}$ square) to separate short fiber. The sieved coco pith was placed in a soaking tank to reduce excess sodium and potassium in coco peat. Calcium nitrate $\left(\mathrm{Ca}\left(\mathrm{NO}_{3}\right)_{2}\right)$ super soluble grade was used for buffering coco peat $(4 \mathrm{~kg}$ per cubic meter of coco peat). After 4-5 times of washings, samples were checked for EC (Electrical conductivity) (using $\mathrm{EC} / \mathrm{pH}$ meter Hanna HI 991003). If EC was less than $0 \mathrm{mS} /$ cm (Negative) the bulk of coco pith were taken out from the tank and was laid on the floor (cement yard) and dried up to 16-20\% moisture content. Then coco pith was separated in to three categories according to their particle size by using a set of sieves i.e. Fine particle $(\leq$ $0.5 \mathrm{~mm})$, medium size particles $(0.5 \mathrm{~mm}<$ medium $\leq 3 \mathrm{~mm})$ and coarse particle $(<4 \mathrm{~mm})$.

Slicing cucumber (Var. Lissome Shallow), bell pepper (Var. Red star), tomato (Var. Ruby) and cabbage (Var. Oxylus) were used as greenhouse vegetables for this experiment. All these varieties were F1 hybrids. Seeds of each of the

Table 1: Mean seed germination percentages of tomato, bell pepper, cucumber and cabbage in media with different particle sizes

\begin{tabular}{lllll}
\hline Particle & \multicolumn{4}{c}{ Mean seed germination percentage } \\
\cline { 2 - 5 } $\begin{array}{l}\text { size of the } \\
\text { media }\end{array}$ & Tomato & $\begin{array}{l}\text { Bell } \\
\text { pepper }\end{array}$ & Cucumber & Cabbage \\
\hline Fine & $68^{\mathrm{b}}$ & $70^{\mathrm{b}}$ & $78^{\mathrm{a}}$ & $94^{\mathrm{a}}$ \\
Medium & $95^{\mathrm{a}}$ & $88^{\mathrm{a}}$ & $84^{\mathrm{a}}$ & $78^{\mathrm{b}}$ \\
Coarse & $80^{\mathrm{b}}$ & $64^{\mathrm{b}}$ & $83^{\mathrm{a}}$ & $60^{\mathrm{c}}$ \\
\hline
\end{tabular}

Means represented by the same letter are not significantly different at $\alpha \leq 0.05$ 
variety was grown in a media consists of each of the three different particle sizes of coco peat.

Prior to seeding, the bulk density, air filled porosity, water holding capacity (using modified methods of De Boodt et al, 1972, 1974), cation exchange capacity (CEC) (using Ammonium sulfate saturation method), electrical conductivity (EC) and $\mathrm{pH}$ (using $\mathrm{EC} / \mathrm{pH}$ meter Hanna HI 991003) were measured in coco peat separated into each particle size. Then the coco peat was placed on nursery trays and wetted. Complete randomized design (CRD) with five replicates was used for this experiment. The seeds were sown in each replicate and covered with black polythene to control the light penetration. Watering was done daily up to germination. Two days after germination, fertilizer application schedule was started. Albert's solutions were used as fertilizer and a stock solution $(2 \mathrm{~kg} / 251$ of water, then $\mathrm{EC}$ is $60 \mathrm{mS} / \mathrm{cm}$ and $5.8 \mathrm{pH}$ ) was prepared. A working solution was prepared from the stock solution $(400 \mathrm{ml}$ of stock solution in 101 of water) and the $\mathrm{EC}$ and $\mathrm{pH}$ values of that solution were adjusted to $1.8 \mathrm{mS} / \mathrm{cm}$ and 5.8 respectively. The working solution was applied to seedlings according to the schedule (within 5 days), starting from 1:5 water dilutions to 1:1 dilutions, to adapt the seedling to the working solution. Five days after seed sowing, germination percentage was recorded and other growth parameters such as seedling height and number of leaves per seedling were recorded at end of the nursery period (17 days after germination of tomato and 21 days after seed germination of other crops).

\section{RESULTS AND DISCUSSION}

According to the analysis of variance, a significant $(\mathrm{p} \leq 0.05)$ variation was observed in germination percentages of tomato, bell pepper, cucumber and cabbage seeds grown in different particle sizes (fine, medium and coarse particles) of coco peat at 5,9 and 7 days after seed sowing. Significantly higher germination percentages of tomato and bell pepper seed (95\%, 88\% respectively) (Table 1) were observed in medium sized particle media when compared to the fine and coarse particles. However, a significantly higher germination percentage of cabbage (94\%) was recorded in the fine particle media (Table 1). The number of leaves per seedling of tomato, bell pepper and cucumber were significantly $(\mathrm{p} \leq 0.05)$ differ among the three different particle sizes of coco peat, where, a significantly higher number of leaves per seedling (7.2 in tomato and 6.1 in bell pepper) were observed in medium sized particle media. However, a significantly higher mean number of leaves per seedling of cucumber was observed in fine and medium particle size coco peat compared to coarse particles. On the other hand, the number of leaves/seedling of cabbage was not significantly different among the particle sizes of coco peat (Table 2). Significant $(\mathrm{p} \leq 0.05)$ differences were not observed in the height of tomato seedlings which were grown in three different particle

Table 2: Mean no of leaves/seedling of tomato, bell pepper, cucumber and cabbage in media with different particle sizes

\begin{tabular}{lllll}
\hline $\begin{array}{l}\text { Particle size of } \\
\text { the media }\end{array}$ & \multicolumn{4}{l}{$\begin{array}{l}\text { Mean no of leaves / seedling at end of } \\
\text { period }\end{array}$} \\
\cline { 2 - 5 } & Tomato & $\begin{array}{l}\text { Bell } \\
\text { pepper }\end{array}$ & Cucumber & Cabbage \\
\hline Fine & $5.5^{\mathrm{b}}$ & $5.0^{\mathrm{b}}$ & $4.8^{\mathrm{a}}$ & $6.5^{\mathrm{a}}$ \\
Medium & $7.2^{\mathrm{a}}$ & $6.1^{\mathrm{a}}$ & $4.6^{\mathrm{a}}$ & $6.3^{\mathrm{a}}$ \\
Coarse & $5.2^{\mathrm{c}}$ & $5.2^{\mathrm{a}}$ & $3.9^{\mathrm{b}}$ & $5.8^{\mathrm{a}}$ \\
\hline
\end{tabular}

Means represented by the same letter are not significantly different at $\alpha \leq 0.05$ 
size of coco peat up to 11 days after germination. However, of the data taken at 14 days and 17 days after germination, significant differences were observed among seedling heights of different coco peat particle sizes. The maximum seedling heights of $14.8 \mathrm{~cm}$ and $17.2 \mathrm{~cm}$ were observed in medium size particle media (sieve size $0.5 \mathrm{~mm}-3 \mathrm{~mm}$ ) at 14 and 17 days after germination respectively compared to the fine and coarse particle sizes. The height of the seedlings which were grown in fine and coarse particles displayed similar height changes during the nursery period of tomato (Figure 1a, Figure 2).

Furthermore, the particle sizes of the coco peat significantly influenced on seedling height of bell pepper from 18 days to 25 days during the nursery period. Similar to tomato, significantly higher mean seedling heights $(13.82 \mathrm{~cm}$ at 18 days and $20.26 \mathrm{~cm}$ at 25 days) were recorded in medium size particles,
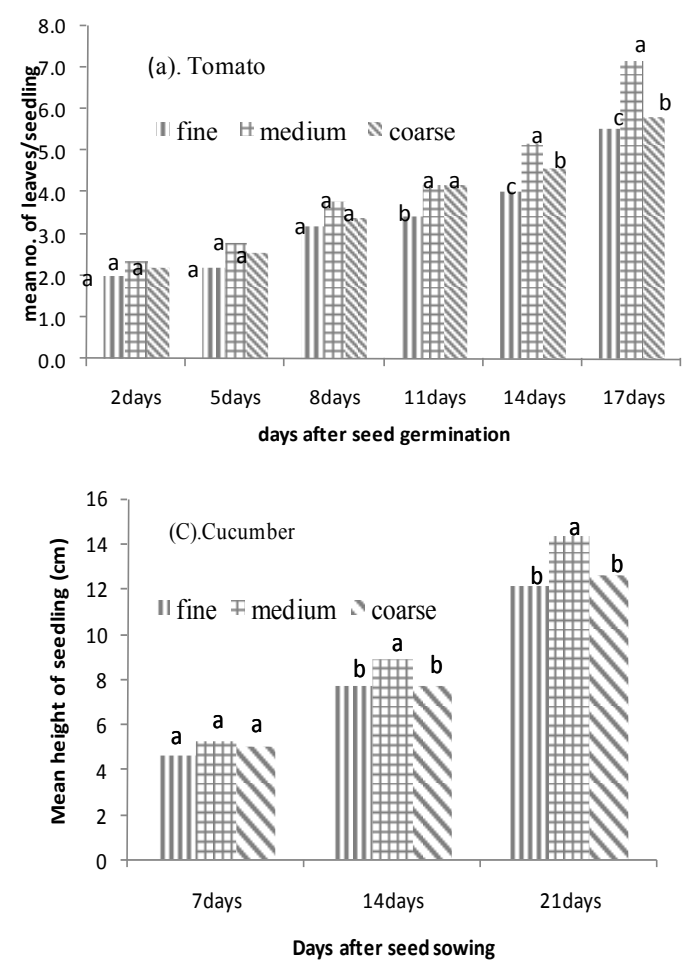

18 and 25 days after seed sowing. The lowest seedling heights were observed in fine and coarse particle medium at 18 and 25 days in the bell pepper nursery (Figure 1b, Figure 3).

The different particle sizes of coco peat had a significant $(\mathrm{p} \leq 0.05)$ impact on seedling height of cucumber at 14 and 21 days after seed sowing. The seedlings in medium size particles had significantly $(\mathrm{p} \leq 0.05)$ higher mean heights $(8.19 \mathrm{~cm}$ at 14 days and $14.3 \mathrm{~cm}$ at 21 days) at 14 and 21 days after seed sowing. Statistically similar and lower mean seedling heights were recorded in fine and coarse particles containing media compared to medium size particles at 14 and 21 days after seed sowing (Figure 1c, Figure 2).

Results revealed that the seedling height of the cabbage was also significantly affected by the particle size of coco peat during the nursery period. At the early stages of growth
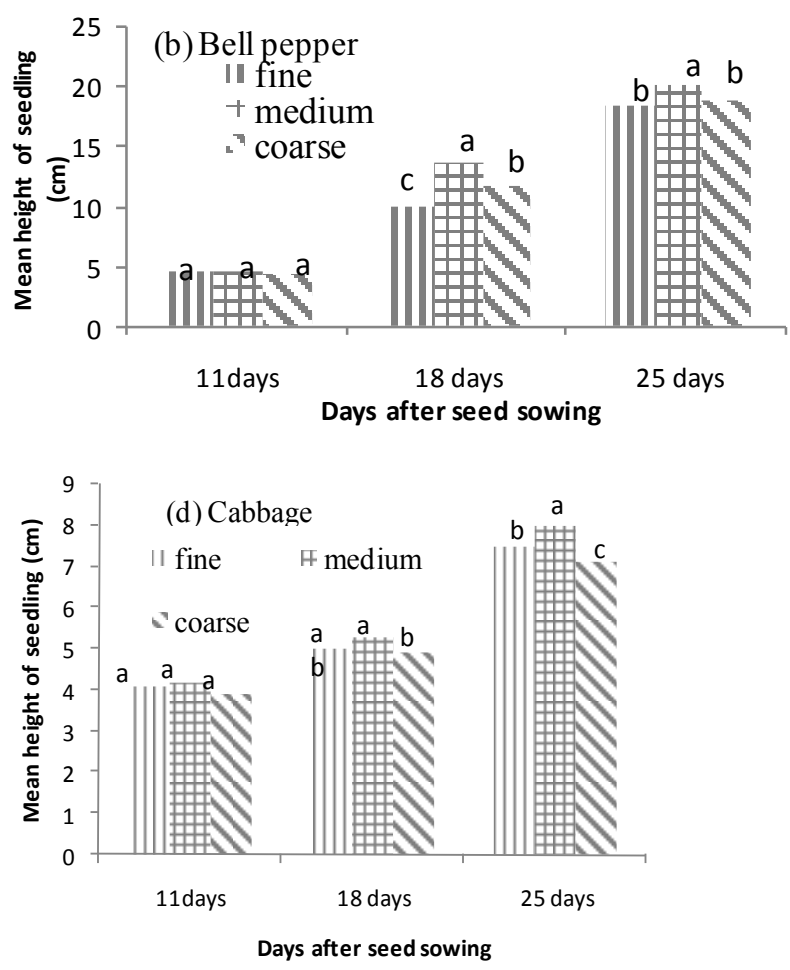

Figure 1. Mean height of seedling of tomato, bell pepper, cucumber and cabbage in media with different particle sizes within nursery period

Means represented by the same letter are not significantly different at $\alpha \leq 0.05$ 
(11days after seed sowing), there was no significant difference on mean seedling heights. However, 18 and 25 days after seed sowing, significantly $(\mathrm{p} \leq 0.05)$ higher seedling heights $(5.3 \mathrm{~cm}$ at 18 days and $8.0 \mathrm{~cm}$ at 25 days) were observed in medium particle media followed by fine particle media $(5.0 \mathrm{~cm}$ at 18 days and $7.5 \mathrm{~cm}$ at 25 days) and coarse (4.9 $\mathrm{cm}$ at 18 days and $7.1 \mathrm{~cm}$ at 25 days) particle media at 18 and 25 days after seed sowing respectively (Figure 1d, Figure 3 ).

The results revealed that the all tested crops had shown higher germination percentages in the medium size particle media. When consider the physical properties of medium particles of coco peat (Table 3 ), it had moderate bulk density $(108.29 \mathrm{~g} / \mathrm{l})$ compared to the fine $(164.3 \mathrm{~g} / \mathrm{l})$ and coarse $(53.82 \mathrm{~g} / \mathrm{l})$ particles. Handreck (1993) reported the nursery media that contains coarse particles create more macro pores and retain low moisture amount and high air content, and thus the available amount of water for seed germination is less in coarse particle media, it may be the reason for lower germination percentages of tomato, bell pepper and cucumber in coarse media. The seeds of cabbage were comparatively small and take relatively short time period for germination, so it showed higher germination percentage in fine and medium sized coco peat media.
Other growth performances such as number of leaves/seedling and seedling height of all crops (tomato, bell pepper, cucumber and cabbage) were higher in medium size particle media with compared to fine and coarse media, because the medium sized media maintains moderate bulk density $(108.29 \mathrm{~g} / \mathrm{l})$ and moderate water holding capacity $(550 \mathrm{ml} / \mathrm{l})$, good air filled porosity $(25 \%)$ and best $\mathrm{pH}$ 6.1. Biernbaum (2001) reported that 15 - $25 \%$ air, 40 $60 \%$ water and $5-7 \mathrm{pH}$ conditions in organic media are the best for vegetable seedling production. Also, Handreck (1993) reported that, when the bulk densities of substrates increase, the pore spaces for air is reduced and as a result, the media retains higher moisture content and low $\mathrm{O}_{2}$ for root growth. Meerow (1995) reported that under low $\mathrm{O}_{2}$ content in the rooting media, nutrient absorption by the root system is low. Also significantly higher EC and CEC was observed in fine particle media, when increase the EC, soluble salt content in the media is increases (Evans et.al., 1996). It makes the stress on vegetative growth of seedlings; this effect might be the reason for lower number of leaves per seedling and low seedling height in fine particle media. Also in opposite way, coarse particles contain lowest bulk density hence it maintains more spores for air and low water and contains low CEC (Table 3), which suppress the growth performances such as no leaves/seedling and seedling height.

Table 3: Physical and chemical properties of media with different particle sizes

\begin{tabular}{lllllll}
\hline $\begin{array}{l}\text { Particle } \\
\text { type }\end{array}$ & $\begin{array}{l}\text { Bulk } \\
\text { density } \\
(\mathbf{g} / \mathbf{l})\end{array}$ & $\begin{array}{l}\text { Water } \\
\text { holding } \\
\text { capacity } \\
(\mathbf{m l} / \mathbf{I})\end{array}$ & $\begin{array}{l}\text { Air filled } \\
\text { porosity } \\
(\% \mathbf{v} / \mathbf{v})\end{array}$ & $\begin{array}{l}\text { Electrical } \\
\text { conductivity } \\
(\boldsymbol{\mu S} / \mathbf{c m})\end{array}$ & $\begin{array}{l}\text { PEC } \\
\text { meq/100g }\end{array}$ \\
\hline Fine & $164.30^{\mathrm{a}}$ & $830^{\mathrm{a}}$ & $12^{\mathrm{c}}$ & $600^{\mathrm{a}}$ & $6.2^{\mathrm{a}}$ & $130^{\mathrm{a}}$ \\
Medium & $108.29^{\mathrm{b}}$ & $550^{\mathrm{b}}$ & $25^{\mathrm{b}}$ & $325^{\mathrm{b}}$ & $6.1^{\mathrm{a}}$ & $86^{\mathrm{b}}$ \\
Coarse & $53.82^{\mathrm{c}}$ & $250^{\mathrm{c}}$ & $68^{\mathrm{a}}$ & $80^{\mathrm{c}}$ & $6.5^{\mathrm{a}}$ & $36^{\mathrm{c}}$ \\
\hline
\end{tabular}

Means represented by the same letter are not significantly different at $\alpha \leq 0.05$ 

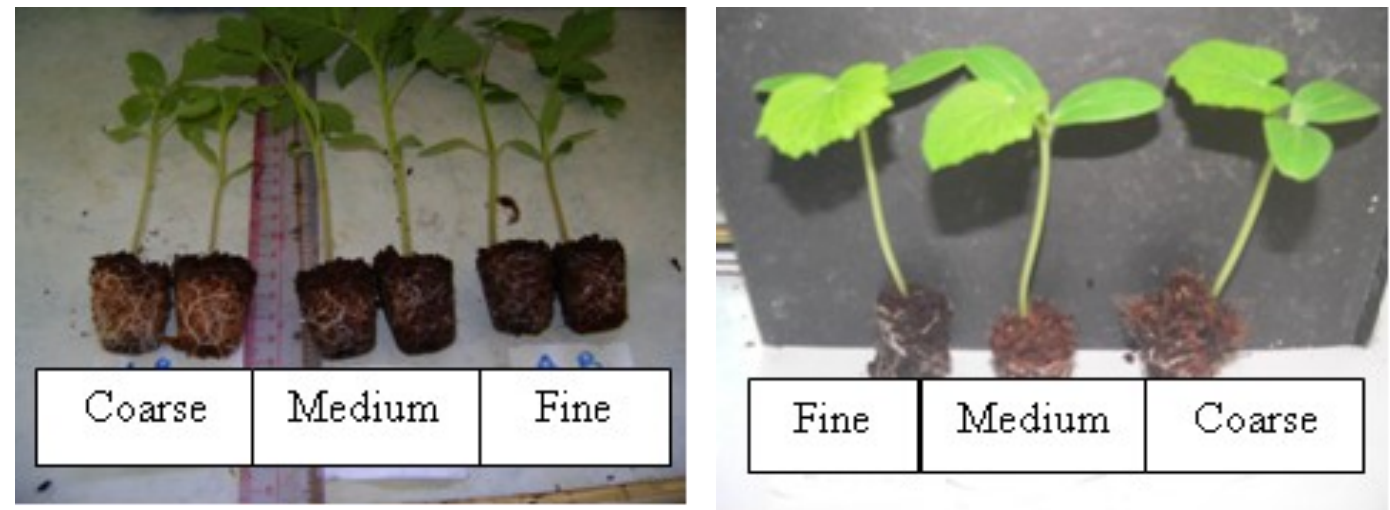

Figure 2: Tomato and cucumber seedlings grown in different particle size media
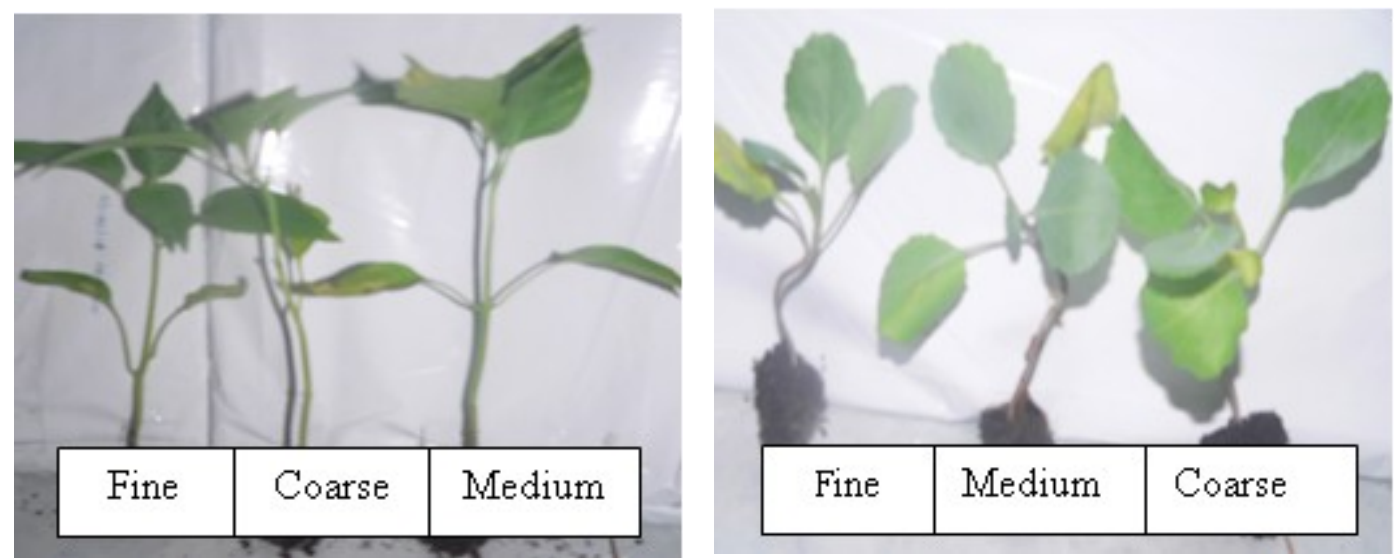

Figure 3: Bell pepper and cabbage seedlings grown in different particle size media

\section{CONCLUSION}

It is evident from the results that the coco peat medium with particle size $0.5 \mathrm{~mm}-3.0 \mathrm{~mm}$ is the best among the three tested particle sizes to obtain higher germination percentages of tomato, bell pepper, slicing cucumber and cabbage. At the same time, the highest seedling growth performances of these crops can be obtained using same particle size medium during the nursery period of 3 weeks.

\section{REFERENCE}

Abad M, Noguera P, Puchades R, Maquieira A. and Noguera V. 2002 Physicochemical and chemical properties some coconut coir dust for use as a peat substitute for containerized ornamental plants. Bioresource Technol- ogy, Vol. 82, pp. 241-245.

Biernbaum J 2001 Organic transplant production for the advanced market gardener. Course materials. Organic University, La Crosse, Wisconsin. 15 March 2001. Midwest Organic and Sustainable Education Service (MOSES), Spring Valley, WI.

De Boodt $\mathrm{M}$ and O Verdonck and I. Cappaert. 1974 Method for measuring the water release curve of organic substrates. Acta Horticulturae, Vol. 37, pp. 20542062.

De Boodt M and O Verdock 1972 The physical properties of the substrates in horticulture. Acta Horticulturae, Vol. 26, pp. 37-44.

Evans MR and Stamps RH 1996 Growth of bedding plants in sphagnum peat and coir dust based substrates. Journal of 
Environmental Horticulture, Vol. 14, pp. 187-190.

Evans MR, Konduru S and Stamps RH 1996 Source variation in physical and chemical properties of coconut coir dust. Hort Science, Vol. 31, pp. 965967.

Handreck AK 1993 Properties of coir dust, and its use in the formulation of soilless potting media. Communications in Soil Science and Plant Analysis, Vol. 24(3\&4), pp. 349-363.

Handreck KA 1992 The use of coir in potting media. Australian Horticulture (November): pp. 54-59.

Kang JY, Lee HH and Kim KH 2004 Physical and Chemical Properties of Inorganic Horticultural Substrates Used in Korea. Acta. Hort., Vol. 644: pp. 237241.

Konduru S, Evans MR and Stamps RH 1999 Coconut husk and processing effects on chemical and physical properties of coconut coir dust. Hort Science, Vol. 34: p. 88.

Mak ATY and Yeh DM 2001 Nitrogen nutrition of Spathiphyllum 'Sensation' grown in sphagnum peat- and coirbased media with two irrigation methods. Hort Science, Vol. 36, pp. 645649.

Meerow AW 1995 Growth of two tropical foliage plants using coir dust as a container media amendment. Hort Technology, Vol. 5, pp. 237-239.

Meerow AW 1994 Growth of two subtropical ornamentals using coir dust (coconut meso- carp pith) as a peat substitute. HortScience, Vol. 29, pp. 1984-1986.

Miller JH and Jones N 1995 Organic and compost-based growing media for tree seedling. Nursries. World Bank Technical Paper, 264.

Nagarajan R, Manickam TS, Lothandaraman GV, Ramasamy $\mathrm{K}$ and Palaniswamy GV 1985 Manurial value of coir pith. Madras Agricultural Journal (B). Vol. 72, pp. 533-535.
Noguera P, Abad M, Noguera V, Puchades R and Maquieira A 2000 Coconut coir waste, a new and viable ecologicallyfriendly peat substitute. Acta Horticulturae, Vol. 517, pp. 279-286.

Noguera P, Abad M, Noguera V, Puchades R and Maquieira A and Martínez J 1997 Physical and chemical properties of coir waste and their relation to plant growth. Acta Horticulturae, Vol. 450, pp. 365373.

Offord CA, Muir S and Tyler JL 1998 Growth of selected Australian plants in soilless media using coir as a substitute for peat. Australian Journal of Experimental Agriculture, Vol. 38, pp. 879887.

Stamps RH and Evans MR 1999 Growth of Dracaena marginata and Spathiphyllum 'Petite' in sphagnum peat and coconut coir dust-based growing media. Journal of Environmental Horticulture, Vol. 17, pp. 49-52.

Stamps RH and Evans MR 1997 Growth of Dieffenbachia maculata 'Camille' in growing media containing sphagnum peat or coconut coir dust. Hort Science, Vol. 32, pp. 844-847. 